\title{
Distribution of Skin Prick Test Results in Rhinitis Allergic Patients at Dr. Hasan Sadikin General Hospital Bandung
}

\author{
Gama Antares, ${ }^{1}$ Arif Dermawan, ${ }^{2}$ Yenti Permata ${ }^{3}$ \\ ${ }^{1}$ Faculty of Medicine Universitas Padjadjaran, ${ }^{2}$ Department of Otorhinolaryngology-Head \\ and Neck Surgery Faculty of Medicine, Universitas Padjadjaran/Dr. Hasan Sadikin General \\ Hospital,Bandung, ${ }^{3}$ Department of Anatomy, Biology Cell and Phsyology Faculty of Medicine \\ Universitas Padjadjaran
}

\begin{abstract}
Background: Allergic Rhinitis (AR) is an inflammation condition in nasal mucous because of type 1 hypersensitivity. Skin prick test is one of the diagnostic tests to diagnose AR. Purpose of this study was to know the distribution of skin prick test in AR patients.

Methods: This study used retrospective descriptive method as cross sectional design. This study was performed from 1 August to 31 October 2014. This study used medical record as secondary data at Department of Otorhinolaryngology-Head and Neck Surgery of Dr. Hasan Sadikin General Hospital. There were 175 cases which fulfilled the inclusion criteria of the study. The data were then analyzed using computer program.

Results: Forty seven cases were positive for house dust (26.8\%), 127 cases were positive for dust mite (72.5\%), 85 cases were positive for rice pollen (48.5\%), 62 cases were positive for maize pollen (35.5\%), 56 cases were positive for mixed fungi (32\%), 100 cases were positive for cockroach (57.1\%), 63 cases were positive for horse dander (36\%), 50 cases were positive for cat dander (28.5\%), 93 cases were positive for dog dander (53.1\%), and 38 cases were positive for chicken feather (21.9\%).

Conclusions: The most aeroallergen making positive result in skin prick test is dust mite. [AM].2017;4(1):129-32]
\end{abstract}

Keywords: Aeroallergen, allergic rhinitis, allergy, skin prick test

\section{Introduction}

Rhinitis is an inflammatory condition of the nasal mucosa which is marked by sneezing, stuffy, runny, and itchy nose. Allergic Rhinitis (AR) is the most common form of rhinitis ${ }^{1,2}$ caused by allergens and mediated by type 1 hypersensitivity process.

The prevalence of AR in both developed and developing countries keeps increasing. The prevalence of AR differs by countries. This difference is probable caused by geographical differences. ${ }^{3}$ The cumulative prevalence of AR is about $20 \%$. In Canada, it is estimated that $20-30 \%$ of the populations suffer from AR. In 2008, it was reported that $2.34 \%$ of the total population in Indonesia suffer from
AR. Meanwhile, the province of West Java has AR prevalence of $3.62 \%{ }^{4}$ Previous studies reported that global AR prevalence keeps increasing. ${ }^{1,5}$

Diagnosis of AR is achieved from history of allergic symptoms, physical examination, and supporting examination. Supporting examination was conducted by using allergens to induce immunoglobulin E (IgE) reaction in AR patients' skin. There are several tests that can be conducted on the skin: skin scratch test, skin prick test (SPT), intradermal test, and patch test. ${ }^{1,6}$

Previous studies reported that out of all the types of supporting examination to diagnose AR, SPT is the most widely used. ${ }^{1}$ This study aimed to discover the distribution of inhaled allergens SPT results among AR patients.

Correspondence: Gama Antares, Faculty of Medicine, Universitas Padjadjaran, Jalan Raya Bandung-Sumedang Km.21, Jatinangor, Sumedang, Indonesia, Phone: +62 8972816537 Email: gamaantares@gmail.com 


\section{Methods}

This was a descriptive study conducted from August 1 to October 31, 2014. This study used the medical records of AR patients with history of inhaled allergens SPT at Department of Otorhinolaryngology-Head and Neck Surgery Dr. Hasan Sadikin General Hospital.

This study collected secondary data from the medical records in the above-mentioned clinic after gaining approval from Health Research Ethics Committee of Dr. Hasan Sadikin General Hospital. The study population was AR patients with history of SPT from January 1 to December 31, 2013. Sampling was collected by total sampling method. The inclusion criterion in this study was AR patients with history of inhaled allergens SPT. A hundred and seventy five AR patients were found with history of SPT. Patients with incomplete medical records were excluded. The collected variables were age, patient's frequency according to gender, inhaled allergens SPT results, and ARIA-WHO classification. The collected data were then analyzed using computer program.

\section{Results}

The patient age characteristic was described in Table 1 . Most of the study subjects were in young adult period (21-40\%). Out of 175 subjects, 69 (39.9\%) were males and 106 $(60.1 \%)$ were females (Table 1$)$. The mean age of the subjects was 29 years old and the median age was 25 years old. The disease severity was mostly from moderate to severe (Table 2).

The SPT results showed that dust mites had the highest percentage $(72.6 \%)$ while chicken feather had the lowest percentage $(21.7 \%)$ (Table 3 and 4).

\section{Discussion}

The AR patients usually complain about stuffy nose, runny nose, sneezing, and itchy nose. AR usually attacks people from the school and productive age groups. Inhaled allergen is the type of allergen that predominantly causes AR. ${ }^{1}$

This study found that there were more female AR patients. This finding is not so different from the previous study by Melati Sudiro et al. ${ }^{7}$ who reported that $55.3 \%$ of AR patients are females. ${ }^{7}$

The age group with the highest frequency was the 21-40 year old group. The largest groups were the school and productive age groups. This was probably because people coming from the two age groups are frequently exposed to some specific allergens. Occurrence of AR symptoms will disturb daily activities to a large extent. Based on that, AR must

Table 1 Patients Frequency based on Gender and Age Group

\begin{tabular}{lcccc}
\hline & $\begin{array}{c}\text { Age group } \\
\text { (years) }\end{array}$ & Male & Gender & Percentage (\%) \\
\cline { 2 - 4 } & 7 & Female & \\
\hline$<10$ & 12 & 26 & 7.4 \\
$11-20$ & 33 & 50 & 21.7 \\
$21-40$ & 15 & 22 & 47.4 \\
$41-60$ & 2 & 2 & 21.1 \\
$61-80$ & 69 & 106 & 2.3 \\
Total & & & 100 \\
\hline
\end{tabular}

Table 2 Patients Frequency based on ARIA-WHO Classification

\begin{tabular}{lcc}
\hline \multicolumn{1}{c}{ Classification } & Number of patients & Percentage \\
\hline Mild intermittent & $\mathbf{3 9}$ & $\mathbf{2 2 . 3}$ \\
Moderate or severe intermittent & 11 & 6.3 \\
Mild persistent & 54 & 30.9 \\
Moderate or severe persistent & 71 & 40.6 \\
\hline
\end{tabular}


Table 3 Results of Skin Prick Test

\begin{tabular}{|c|c|c|c|c|c|}
\hline Allergen & - & + & ++ & +++ & ++++ \\
\hline House dust & 128 & 13 & 17 & 14 & 3 \\
\hline Dust mites & 48 & 16 & 18 & 36 & 57 \\
\hline Rice pollen & 90 & 22 & 26 & 28 & 9 \\
\hline Maize pollen & 113 & 25 & 22 & 14 & 1 \\
\hline Mixed fungi & 119 & 26 & 15 & 11 & 4 \\
\hline Cockroaches & 75 & 21 & 31 & 33 & 15 \\
\hline Horse dander & 112 & 28 & 16 & 16 & 3 \\
\hline Cat dander & 125 & 19 & 11 & 14 & 6 \\
\hline Dog dander & 82 & 17 & 18 & 30 & 28 \\
\hline Chicken feather & 137 & 15 & 11 & 11 & 1 \\
\hline
\end{tabular}

Table 4 Distribution of SPT Results based on Positive Grade

\begin{tabular}{lccccc}
\hline \multicolumn{1}{c}{ Allergen } & $+\boldsymbol{\& + +}$ & Percentage & $\mathbf{+ + + \boldsymbol { + + + + }}$ & Percentage & Total \\
\hline House dust & 30 & 17.1 & 17 & 9.7 & $47(26.8)$ \\
Dust mites & 34 & 19.4 & 93 & 53.1 & $127(72.5)$ \\
Rice pollen & 48 & 27.4 & 37 & 21.1 & $85(48.5)$ \\
Maize pollen & 47 & 26.9 & 15 & 8.6 & $62(35.5)$ \\
Mixed fungi & 41 & 23.4 & 15 & 8.6 & $56(32)$ \\
Cockroaches & 52 & 29.7 & 48 & 27.4 & $100(57.1)$ \\
Horse dander & 44 & 25.1 & 19 & 10.9 & $63(36)$ \\
Cat dander & 30 & 17.1 & 20 & 11.4 & $50(28.5)$ \\
Dog dander & 35 & 20.0 & 58 & 33.1 & $93(53.1)$ \\
Chicken feather & 26 & 14.9 & 12 & 6.9 & $38(21.8)$ \\
\hline
\end{tabular}

be diagnosed accurately and given rational treatment. Unsuitable treatment will result in decreased work productivity and loss of academic time in students. ${ }^{7}$

The SPT results of AR patients were also observed in this study. The highest number of positive result came from dust mites. This conforms to a study in Korea. ${ }^{8}$ The Korean study discovered that dust mites are the most dominant inhaled allergen. ${ }^{8}$ However, another study in Iran9 found that dust mite allergy is only positive in $20 \%$ of the subjects. ${ }^{9}$ On the contrary, Saleh et al. ${ }^{10}$ found that the allergen with the most positive results is mold. ${ }^{10}$ The difference in the dominant allergens can be attributed to the different demographic factors which can influence the types of allergen presence in there. ${ }^{1}$

The high number of positive SPT results caused by dust mites in this study was made possible by frequent exposure to the allergen. The habitat of dust mites was in many places in the house: mattresses, beds, and bed sheets. Dust mites grow well in the tropical climate. ${ }^{11,12}$ Dust mite allergens come from their body parts or the digestive enzymes contained in their feces. ${ }^{12-14}$ The continuous exposure can induce the human immune system to be sensitized against certain allergens.

The findings of this study were in agreement by a previous study which found that the moderate or severe persistent AR has the highest frequency compared to the other types. ${ }^{7}$

One limitation of this study was that the data used in this study were only collected from the medical records at Department of Otorhinolaryngology-Head and Neck Surgery 
Dr. Hasan Sadikin General Hospital in 2013.

It is suggested to conduct further studies with larger population, more comprehensive variables, and more extensive discussion. Medical records should also be written in legible handwriting to expedite studies on AR cases. Common people should pay more attention to the cleanliness of their houses and workplaces to prevent exposure of dust mites.

The conclusion of this study is that dust mites are the allergen with highest positive SPT results. The 20-40 year old age group is the group with the highest frequency. Based on ARIA-WHO classification, the type of AR with highest number is moderate or severe persistent AR.

\section{References}

1. Bousquet J, Khaltaev N, Cruz AA, Denburg J, Fokkens WJ, Togias A, et al. Allergic rhinitis and its impact on asthma (ARIA) 2008 update (in collaboration with the World Health Organization, GA(2)LEN and AllerGen). Allergy. 2008;63 Suppl 86:8160.

2. Pawankar R, Canonica G, Holgate S, Lockey R, Editors. WAO white book on allergy 2011-2012: executive summary. Winconsin: World Allergy Organization; 2011.

3. Lima RG, Pastorino AC, Casagrande RR, Sole D, Leone C, Jacob CM. Prevalence of asthma, rhinitis and eczema in 6 - 7 years old students from the western districts of Sao Paulo City, using the standardized questionnaire of the "International Study of Asthma and Allergies in Childhood" (ISAAC)-phase IIIB. Clinics (Sao Paulo). 2007;62(3):225-34.

4. Departemen Kesehatan Republik Indonesia. Riset Kesehatan Dasar (RISKESDAS) 2007. Jakarta: Badan Penelitian dan Pengembangan Kesehatan Departemen Kesehatan Republik Indonesia; 2008.

5. Shah A, Pawankar R. Allergic rhinitis and co-morbid asthma: perspective from India-
ARIA Asia-Pacific Workshop report. Asian Pac J Allergy Immunol. 2009;27(1):71-7.

6. Bauchau V, Durham SR. Prevalence and rate of diagnosis of allergic rhinitis in Europe. Eur Respir J. 2004;24(5):758-64.

7. Melati Sudiro, Teti Madiadipoera, Purwanto Bambang. Eosinofil kerokan mukosa hidung sebagai diagnostik rinitis alergi. MKB. 2005;42(1):6-11.

8. Shin JH, Kim BG, Cho JH, Kim SW, Lee BJ, Kim YW, et al. Skin prick testing of patients with allergic rhinitis and/or Asthma: a study in Catholic Medical Center, Korea. J Rhinol. 2012;19(1):29-34.

9. Fereidounia M, Hossinia RF, Azada FJ, Assarehzadegan MA, Varasteh A. Skin prick test reactivity to common aeroallergens among allergic rhinitis patients in Iran. Allergol Immunopathol (Madr). 2009;37(2):73-9.

10. Saleh BT, Abd AI, Saleh RI, Mohammed TS, Aljubory AH. A study of Skin prick test reactivity to common aeroallergens among patients with allergic rhinitis in Salahelden Governorate. Tikrit J Pure Sci. 2011;16(4):40-4.

11. Tsai1 LC, Peng HJ, Lee CS, Chao PL, Tang RB, Tsai JJ, et al. Molecular cloning and characterization of full-length cDNAs encoding a novel high-molecular-weight Dermatophagoides pteronyssinus mite allergen,Derp11.Allergy.2005;60(7):92737.

12. Nurmatov U, van Schayck CP, Hurwitz B, Sheikh A. House dust mite avoidance measures for perennial allergicrhinitis: an updated Cochrane systematic review. Allergy. 2012;67(2):158-65.

13. Shin JW, Sue JH, Song TW, Kim KW, Kim ES, Sohn MH, et al. Atopy and house dust mite sensitization as risk factors for asthma in children. Yonsei Med J. 2005;46(5):62934.

14. Jeong KY, Park JW, Hong CS. House dust mite allergy in Korea: the most important inhalant allergen in current and future. Allergy Asthma Immunol Res. 2012;4(6):313-25. 